\title{
NEW MAPPING IN THE WESTERN PART OF UBEKENDT EJLAND
}

\author{
D. B. Clarke
}

\section{Introduction}

During the period August 6-18 the writer, assisted by C. Wewer, worked on Ubekendt Ejland. From the base camp at the mouth of Tuperssuartûta kûa three areas were covered and Wewer later collected in the fourth from the GGU ship "K. J. V. Steenstrup". The areas (see fig. 2) were:

(a) a portion of the south-western coast (overlapping with the work of Jørgen Gutzon Larsen)

(b) Tuperssuartûta kûa

(c) Itivnera valley as far as the west coast at $71^{\circ} 11^{\prime} \mathrm{N}$

(d) west coast south of $71^{\circ} 11^{\prime} \mathrm{N}$ (C. Wewer)

On return to Dalhousie University fifty-five thin sections were cut and examined with a view to future analytical work. The four areas studied will be discussed individually. The field relations will be described first and a brief account of the petrology of the rocks will follow.

\section{South-western coast}

This section covers the coast from approximately $71^{\circ} 04^{\prime} 30^{\prime} \mathrm{N}$ to Erqua. It begins in a thick sequence of tuffs belonging to the Upper Lava Group of Drever \& Game (1948). The pyroclastics tend to be acid in composition and consist largely of fresh or devitrified glass fragments, occasional xenoliths, crystal fragments of kaolinized potash feldspar, quartz and veins and patches of carbonate.

These tuffs are overlain by approximately $200 \mathrm{~m}$ of relatively thin flows of feldspar-phyric basalt, with minor olivine basalts and tuffaceous horizons. Overlying this is another $300 \mathrm{~m}$ of pyroclastics including some ignimbrites and two pitchstone flows. The pitchstones consist of brown glass with perlitic cracks, pheno- 


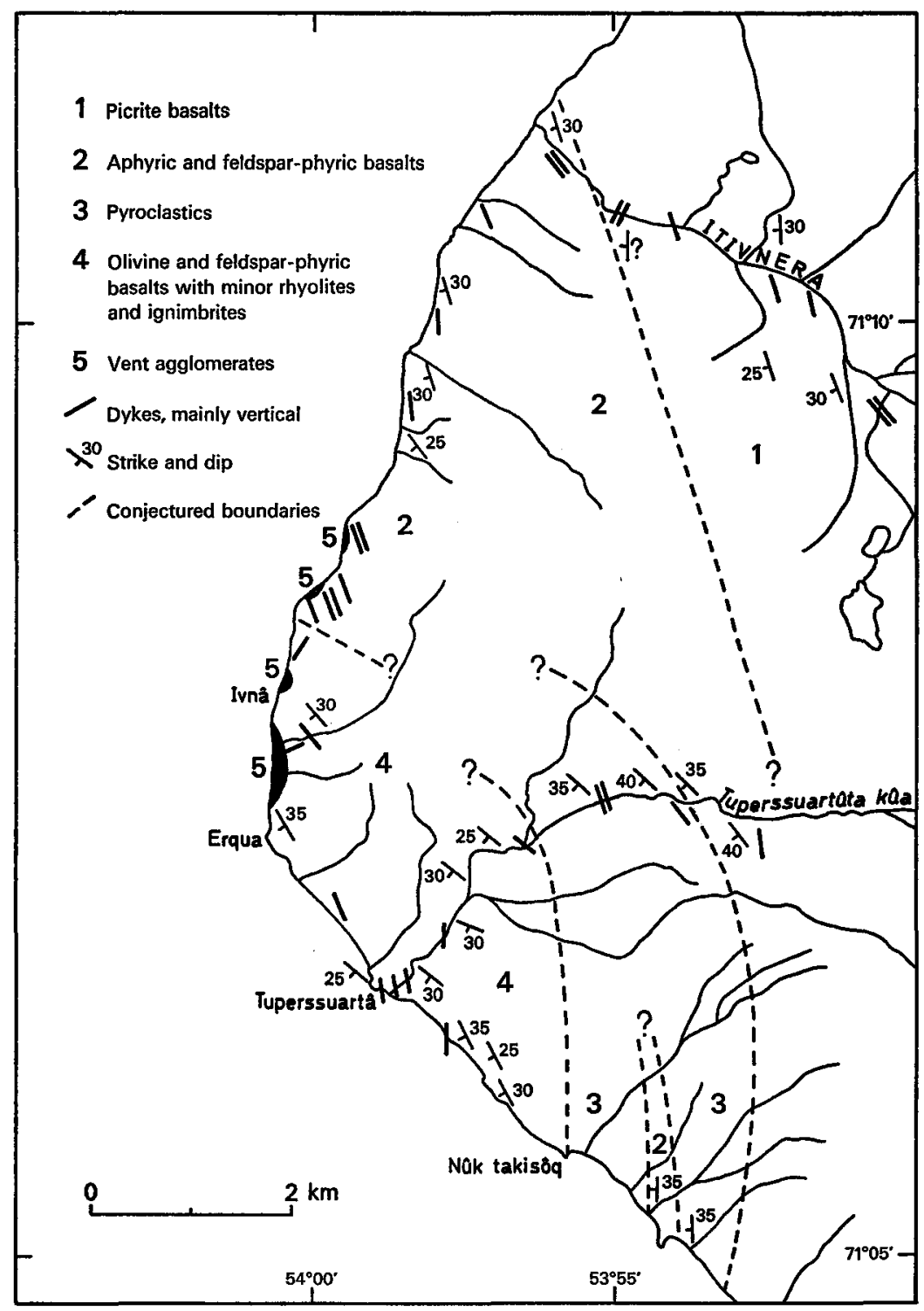

Fig. 2. Geological sketch map of western Ubekendt Ejland. 
crysts of sanidine partly replaced by carbonate, and xenoliths of highly altered basalt. The pyroclastics end at Nûk takisôq and the rest of the coast to Erqua consists of altered olivine basalts in which the olivines have been pseudomorphed by serpentine, iddingsite and carbonate, minor acid flows and frequent thin pyroclastic horizons. The point at Erqua is an olivine basalt with microphenocrysts of both olivine and plagioclose.

A few dykes of basaltic or lamprophyric composition cut this part of the volcanic pile. Two of these carry large amounts (up to 25 per cent) of xenoliths, both ultramafic and basement varieties.

In summary, the flows are generally basaltic and the pyroclastic material is generally acid in composition. The few acid flows in Tuperssuartûta kûa do not appear to continue along strike down to the south coast.

\section{Tuperssuartûta kûa}

Good exposures begin in a gorge at $71^{\circ} 07^{\prime} 30^{\prime \prime}, 53^{\circ} 53^{\prime} 30^{\prime \prime} \mathrm{W}$ where thin, greenish basaltic flows and lamprophyric(?) dykes outcrop. Downstream the river then passes for a distance of $2.0-2.5 \mathrm{~km}$ through a fairly uniform volcanic breccia which gives the appearance of being more stratified near the top of this unit. Brown weathering, resistant and thick, olivine-poor basaltic flows, along with some altered rhyolites, gradually appear among the pyroclastics, which decrease in importance to about 20 per cent of the section at the mouth of the river. Both the basalts and rhyolites in this region are extensively replaced by carbonate. The pyroclastics in the lower reaches of the river tend to be thin, rather poorly exposed, welded tuffs. These consist of devitrified but welded glass fragments, kaolinized feldspar, quartz and some possible recrystallized basement xenoliths. Also, in this region there occur loose pieces of fossilized wood which may suggest the existence of thin sedimentary horizons nearby.

There are numerous lamprophyric dykes striking NNW in the lower reaches of the river, one of which is extremely rich in basement xenoliths. The compositional range of these rocks has not been fully determined, but a frequent mineral assemblage is plagioclase - olivine - titaniferous clinopyroxene - biotite hornblende (xenocrysts) - magnetite.

\section{Itivnera}

The main river valley and some tributaries were mapped from $71^{\circ} 09^{\prime} 00^{\prime \prime} \mathrm{N}$, $53^{\circ} 50^{\prime} 30^{\prime \prime} \mathrm{W}$ to the coast. The section in the upper part of the river consists of thin picritic flows which weather red, green and purple and consist of 
large amounts of chlorite, serpentine and zeolites. This part of the section also contains approximately 10 per cent of light coloured flows. The only thin section available for this rock type revealed that these are now fine-grained, porphyritic quartzo-feldspathic rocks extensively sericitized and replaced by carbonate. Their original affinities are probably rhyolitic.

In the central part of the river valley the thin picritic flows give way to more feldspar-phyric and massive aphyric basaltic flows. However, in the lower reaches of the river the thin picrites return along with some thick, fresh massive picrites and some thick aphyric basaltic flows. The lower part of the river is structurally complex and difficult to investigate because there is little outcrop on the north side of the valley, and the south wall of the valley is upheld by one or another of several vertical basaltic and/or lamprophyric dykes. The lamprophyres consist of strongly zoned clinopyroxene, serpentinized olivine, biotite, magnetite and finegrained groundmass feldspar.

\section{West coast}

Several small diatremes outcrop along the coast immediately north of Erqua to somewhat beyond Ivna. The intrusions are characterized by agglomerates consisting of rounded basaltic blocks and fragments largely replaced by carbonate. Many also contain broken crystal fragments of orthoclase and quartz. The matrix between the xenoliths is essentially carbonate although some chlorite and zeolites do occur. The agglomerate is often cut by late veins and stringers of quartz and carbonate. Petrologically, there is a strong resemblance between some of the diatreme material and the carbonate dykes of south-western Svartenhuk.

Nearly all the volcanics in the vicinity of the diatremes were originally olivinepoor, feldspar-phyric to aphyric basalts. The effect of the diatremes is manifested by carbonate replacement in the volcanics found throughout the mapped area. From $71^{\circ} 09^{\prime} \mathrm{N}$ to $71^{\circ} 11^{\prime} \mathrm{N}$ the coastal outcrops consist of a monotonous sequence of largely aphyric basalts.

Many kersantitic dykes striking NNW and dipping vertically are exposed along the west coast. These too are highly altered by the introduction of carbonate.

\section{Structure}

Except for some complexities not fully investigated in the lower reaches of the Itivnera valley and in the vicinity of the diatremes, the structural pattern of the area investigated is relatively simple. The volcanics tend to strike NW and dip SW at angles from $15-60^{\circ}$, an average being close to $30^{\circ}$. The dykes over most 
of the area strike NW to NNW and dip vertically except in the region of the diatremes where the strike of the dykes is highly variable. No major faults were recognized.

\section{Discussion and conclusions}

Nearly three hundred samples were collected in the field with a view to doing subsequent chemical work. The objectives of this proposed work were twofold, (a) to better understand the history of magmatic evolution in the West Greenland Tertiary lava province, and (b) to establish how far the linear increase in incompatible trace elements could be traced in the evolved rocks for the purpose of establishing the stratigraphic position of samples dredged offshore.

The disappointing degree of alteration in these rocks, in spite of their generally "fresh" appearance, will make any geochemical study of questionable value in terms of understanding the original chemical variation in these rocks. The project is now being reconsidered in the light of this new development. It may, instead, be necessary to focus attention on such things as: (a) isotopic composition and possible origin of the diatremes, (b) chemical variation and evolution of the lamprophyres (which are least affected by alteration), (c) microprobe investigations of coexisting pyroxenes in the lamprophyres, (d) study of contamination of the lamprophyres by basement xenoliths or (e) investigation of the possible cognate origin of the ultramafic xenoliths in the lamprophyres.

There are two interesting aspects of the field observations that are worth further investigation. The first of these is that, although there is an abundance of xenoliths of ultrabasic and Precambrian basement material in some of the flows and dykes, there is a total lack of any Cretaceous-Tertiary sedimentary xenoliths. This might suggest a local absence of pre-volcanic sediments under Ubekendt Ejland, as there is under part of Disko.

The second observation is that the typical, very thick, brown feldspar-phyric basalts of Svartenhuk Halvø, Nûgssuaq and Disko appear to be absent from Ubekendt Ejland. If this is true then some possible reasons may be (a) the thick feldspar-phyric flows were not as widespread as previously believed, (b) the feldspar-phyric basalts have been eroded from Ubekendt Ejland and replaced by the unique Upper Lava Group found there, (c) feldspar-phyric basalt flows were widespread but central volcanoes in Ubekendt Ejland stood as "islands" in the plateau basalt sequence.

\section{Reference}

Drever, H. I. \& Game, P. M. 1948: The geology of Ubekendt Ejland, West Greenland. Part 1. A preliminary review. Meddr Grønland 134, 8, 35 pp. 